\section{PROFILE OF NEWBORNS WITH GASTROSCHISIS DIAGNOSIS in a Public hospital at Porto Alegre/RS}

\author{
Greice Kelli Coelho de Souza', Márcia Rejane Strapasson¹, \\ Edegar Fronza ${ }^{2}$, José Geraldo Lopes Ramos ${ }^{3}$
}

\begin{abstract}
Objective: To know the profile of newborn diagnosed with gastroschisis and treated at a public hospital at Porto Alegre, southern Brazil.

Method: A cross-sectional, descriptive, quantitative study was conducted to retrospectively analyze 54 medical records of neonates diagnosed with gastroschisis treated the study hospital between January 2006 and January 2016. The analysis included all medical records of infants diagnosed with gastroschisis and born in the institution studied, as well as those who were transferred from other health institutions in the period examined. Medical records were searched through electronic consultation to the institution's Epidemiology Service, using the International Code of Diseases (ICD) 10 Q 793). Later, the files were accessed through the Medical Records and Statistics Service. Information was collected using a form containing the study variables. The data analysis was performed using SPSS software, version 21.0. The study complied with the ethical aspects of human research legislation.
\end{abstract}

Results: The prevalence of gastroschisis was $0.11 \%$, totaling 54 cases identified. Mean maternal age was 20.2 years; sex distribution was equal among newborns with the malformation; and $72.5 \%$ of cases had primary abdominal closure.

Conclusion: The results for related causes and treatment, such as maternal age, drug use, and type of abdominal closure, were similar to findings from other studies on gastroschisis.

Keywords: Congenital anomalies; gastroschisis; nursing care; neonatal nursing

Changes in embryonic development, whether structural or functional, may result in congenital anomalies affecting one or more organs ${ }^{1}$. Gastroschisis is a congenital malformation characterized by incomplete closure of abdominal wall and protrusion of intestines outside bowel appears outside the infant's abdominal cavity ${ }^{2,3}$.

The prevalence of malformations in Brazil is similar to that found in other world regions ${ }^{4}$. Gastroschisis is associated with low maternal age ( $<20$ years), smoking, consumption of illegal drugs, and use of vasoactive drugs $^{2}$. Its incidence has increased in recent decades, ranging from one to five cases per 10,000 live births. This increase is related to increased exposure to risk factors known so far ${ }^{5}$.

At-risk mothers include those in very early or in advanced reproductive age. Maternal physiological immaturity is believed to cause serious maternal-fetal complications. However, pregnancy in women over 35 years of age is considered risky due to hormone and biochemical deficiencies that these women may have ${ }^{6}$.

The benefits of prenatal diagnosis of gastroschisis involve family support, birth planning, and specific care protocols ${ }^{2}$. Birth planning and the choice of mode of delivery are extremely important, with cesarean section being the mode of choice because it poses less risk of infection in neonates with
Clin Biomed Res. 2017;37(1):25-32

1 School of Nursing, Universidade do Vale do Rio dos Sinos (UNISINOS). São Leopoldo, RS, Brasil.

2 Center of Biological and Health Sciences, Universidade de Caxias do Sul (UCS).

Caxias do Sul, RS, Brasil.

3 Department of Gynecology and Obstetrics, School of Medicine, Universidade Federal do Rio Grande do Sul (UFRGS). Porto Alegre, RS, Brasil.

Corresponding author:

Greice Kelli Coelho de Souza greice.kellisouza@yahoo.com.br Universidade do Vale do Rio dos Sinos (UNISINOS)

Av. Unisinos, 950.

93022-750, São Leopoldo, RS, Brasil. 
exposed viscera. Thus, early prenatal diagnosis of gastroschisis may significantly reduce time to corrective surgery for this neonatal complication?

Newborns (NBs) with gastroschisis have a very variable prognosis, possibly requiring prolonged hospital stay, intensive care, antibiotic therapy, parenteral nutrition, and surgical treatment. Improved survival rates for gastroschisis result from appropriate surgical and clinical treatment both in the immediate postpartum period and in the intensive care setting. Within this context, the recommended treatment involves primary abdominal wall closure and secondary closure if necessary ${ }^{8,9}$. Abdominal closure leads to reduced risk of bacterial loop contamination, sepsis, hypothermia, and metabolic dysfunctions. Primary closure consists of abdominal fascial closure after reduction of eviscerated loops, and staggered (or secondary) closure uses a silo to hold the exposed loops and reduce them gradually after surgery, resulting in the correction of the defect or including surgical reinterventions 5 to 10 days after primary closure ${ }^{7}$. The most common postoperative complications consist of necrotizing enterocolitis, short bowel syndrome, malabsorption, intestinal obstruction, and cholestasis, due to prolonged use of parenteral nutrition ${ }^{9,10}$, but neonate dietary tolerance is increased when diet is gradually started with smaller volumes ${ }^{11}$.

The relevance of the present study lies on the importance of gastroschisis as an abdominal wall malformation considered as a rare event with a multifactorial etiology ${ }^{12}$. The general aim of the study was to investigate the profile of NBs diagnosed with gastroschisis and treated at a large public hospital in Porto Alegre, southern Brazil. Its specific aims were to identify the prevalence of gastroschisis in that hospital, to determine the sociodemographic and obstetric profile of pregnant women whose infants were diagnosed with gastroschisis, and to describe perinatal outcomes of cases of gastroschisis.

\section{METHODS}

A cross-sectional descriptive, quantitative, retrospective study was conducted in a large public hospital in Porto Alegre, southern Brazil. The maternity ward of the hospital supports education and research and is a reference center for at-risk pregnant women from Porto Alegre, its metropolitan region, and the state of Rio Grande do Sul.

The sample consisted of medical records of neonates diagnosed with gastroschisis and treated at the study hospital from January 1st, 2006 to January 1 st, 2016 . The analysis included all medical records from infants with gastroschisis and other associated malformations born at the study institution or transferred from other institutions.

For this study, mean delivery rate was considered to be 4,800 deliveries per year, with the assessment of all medical records from NBs with gastroschisis treated at the analyzed hospital within the established time frame.

Medical records were searched through electronic consultation to the institution's epidemiology service using the International Code of Diseases (ICD) 10 Q 79.3 and were subsequently accessed through the Medical Records and Statistics Service. The information obtained was recorded on a data collection form and then inserted into an Excel database. Data were analyzed using descriptive statistics expressed as absolute and relative frequency for categorical variables and as mean and standard deviation for quantitative variables. The Pearson's chi-square test was applied to assess the association between categorical variables. When associations were statistically significant, adjusted residual analysis was used. Statistical analysis was performed using SSPS, version 21.0. The level of significance was set at $5 \%(p \leq 0.05)$.

Variables were characterized as follows: maternal data (age, skin color, educational level, origin, occupation); clinical-obstetric data (gestational age, maternal blood type, number of prenatal visits, parity, prenatal diagnosis of gastroschisis, previous disease, complications during pregnancy, medication use during pregnancy, alcohol or tobacco use during pregnancy, use of other illegal drugs, family history of malformations, mode of delivery); and perinatal data (NB sex, NB birth weight, gestational age as assessed by the Capurro method, 1- and 5-minute Apgar scores, other associated malformations, type of abdominal closure, postnatal death).

The present study was conducted according to ethical regulations for human subjects research set forth in the Brazilian National Health Council Resolution no. 466/12 and was approved by the Research Ethics Committees of Universidade do Vale do Rio dos Sinos (UNISINOS) and of the co-participating institution, under protocol number 1.396.618/2015.

\section{RESULTS}

According to the collected data, the prevalence of gastroschisis was $0.11 \%$, with a $95 \%$ confidence interval from $0.9 \%$ to $1.5 \%$.

Among the 54 medical records from neonates with gastroschisis, mean maternal age was 20 years. Most women reported themselves as white and more than $30 \%$ reported to have above 8 years of education. More than a half of mothers of infants 
with gastroschisis reported not to perform any paid work activity (table 1).

As for maternal place of origin, $51 \%$ of mothers came from other cities through transfer of neonate or mother from other health institutions (table 1).

Obstetric findings showed a mean gestational age of 36.6 weeks and a mean of six prenatal visits. More than $80 \%$ of cases of gastroschisis were diagnosed during prenatal care. Regarding mode of delivery,

Table 1: Sociodemographic profile of mothers of infants with gastroschisis $(n=54)$.

\begin{tabular}{|c|c|c|}
\hline Variables & $\begin{array}{l}\text { Subjects } \\
\text { n (\%) }\end{array}$ & $\begin{array}{c}\text { Descriptive } \\
\text { statistics } \\
\text { n (\%) }\end{array}$ \\
\hline $\begin{array}{l}\text { Maternal age (years) - } \\
\text { mean } \pm S D\end{array}$ & $46(85.2)$ & $20.2 \pm 3.9$ \\
\hline Maternal skin color & $36(66.7)$ & \\
\hline White & & $33(91.7)$ \\
\hline Black & & $3(8.3)$ \\
\hline Maternal educational level & $32(59.3)$ & \\
\hline Illiterate & & $2(6.3)$ \\
\hline $\begin{array}{l}\text { Incomplete elementary } \\
\text { school }\end{array}$ & & $4(12.5)$ \\
\hline $\begin{array}{l}\text { Complete elementary } \\
\text { school }\end{array}$ & & $8(25.0)$ \\
\hline Incomplete high school & & $11(34.4)$ \\
\hline Complete high school & & $6(18.8)$ \\
\hline $\begin{array}{l}\text { Incomplete higher } \\
\text { education }\end{array}$ & & $1(1.9)$ \\
\hline Region of origin & $51(94.4)$ & \\
\hline Porto Alegre & & $10(19.6)$ \\
\hline Metropolitan region & & $15(29.4)$ \\
\hline Countryside & & $26(51.0)$ \\
\hline Paid work & $32(59.3 \%)$ & \\
\hline Yes* & & $13(40.6)$ \\
\hline No & & $19(59.4)$ \\
\hline $\begin{array}{l}\text { Number of pregnancies - } \\
\text { median (P25 - P75) }\end{array}$ & $42(77.8)$ & $1(1-2)$ \\
\hline Previous vaginal delivery & $39(72.2)$ & $11(28.2)$ \\
\hline Previous cesarean section & $39(72.2)$ & $3(7.7)$ \\
\hline Miscarriage/abortion & $35(64.8)$ & $3(8.6)$ \\
\hline Maternal blood type & $37(68.5)$ & \\
\hline$A+$ & & $15(40.5)$ \\
\hline A- & & $2(5.4)$ \\
\hline $\mathrm{O}+$ & & $14(37.8)$ \\
\hline O- & & $1(2.7)$ \\
\hline $\mathrm{B}+$ & & $5(13.5)$ \\
\hline Previous disease ${ }^{\star *}$ & $36(6.7)$ & $4(11.1)$ \\
\hline
\end{tabular}

Source: designed by the author. Study data (2016). *Salesperson $(n=3)$; manicure $(n=2)$; servant $(n=1)$; shoemaker $(n=1)$; receptionist $(n=1)$; assistant $(n=1)$; general service assistant $(n=1)$; maid $(n=1)$; guard $(n=1)$; cashier operator $(n=1)$; ${ }^{* *}$ Gestational diabetes mellitus $(n=1)$; hypertension + diabetes mellitus $(\mathrm{n}=1)$; hypothyroidism $(\mathrm{n}=1)$; pyelonephritis $(n=1)$; SD: standard deviation; md: median; P25: 25th percentile; P75: 75th percentile.
$79.2 \%$ of infants were born by cesarean section, whereas $20.8 \%$ of those diagnosed prenatally were born by vaginal delivery (table 2 ).

More than $50 \%$ of pregnant women had some complication during pregnancy, the most common of which was urinary tract infection (UTI) $(50 \%)$ (figure 1). The most commonly used medications to treat this condition were amoxicillin and cefalexin, both used in $16.7 \%$ of cases (figure 2 ).

As for the profile of NBs with gastroschisis, sex distribution was equal, i.e., $50 \%$ for each sex. Mean birth weight was $2,427 \mathrm{~g}$, and mean gestational age by the Capurro method was 37.8 weeks. Mean 1 - and 5-minute Apgar scores were 8 and 9, respectively. No death was reported among neonates born at the study institution in the immediate postpartum period or in the delivery room. However, $7.4 \%$ of medical records reported death in the late postpartum period from in-hospital complications, all of which described as septic shock (table 3 ).

Of the cases analyzed, $72.5 \%$ underwent primary closure and $27.5 \%$ underwent secondary closure. Median time from birth to primary closure was 2.5 hours (table 3) (figure 3 and 4). Of the cases assessed, 40\% had some malformation associated with gastroschisis,

Table 2: Obstetric profile of mothers of infants with gastroschisis $(n=54)$.

\begin{tabular}{|c|c|c|}
\hline Variables & $\begin{array}{c}\text { Total } \\
\text { sample } \\
\text { n (\%) }\end{array}$ & $\begin{array}{c}\text { Descriptive } \\
\text { statistics } \\
\text { n (\%) }\end{array}$ \\
\hline $\begin{array}{l}\text { Gestational age } \\
\text { (weeks) }- \text { mean } \pm \text { SD }\end{array}$ & $52(96.3)$ & $36.6 \pm 1.9$ \\
\hline $\begin{array}{l}\text { Number of prenatal } \\
\text { visits - mean } \pm S D\end{array}$ & $46(85.2)$ & $6.9 \pm 2.7$ \\
\hline $\begin{array}{l}\text { Prenatal diagnosis of } \\
\text { gastroschisis }\end{array}$ & $41(75.9)$ & $34(82.9)$ \\
\hline Singleton pregnancy & $47(87.0)$ & $44(93.6)$ \\
\hline Complications & $42(77.8)$ & $22(52.4)$ \\
\hline $\begin{array}{l}\text { Use of medication } \\
\text { during pregnancy }\end{array}$ & $33(61.1)$ & $24(72.7)$ \\
\hline Smoking & $32(59.3)$ & 7 (21.9) \\
\hline Alcohol use & $31(57.4)$ & $1(3.2)$ \\
\hline Use of illegal drugs & $32(59.3)$ & $2(6.3)$ \\
\hline $\begin{array}{l}\text { Family history of } \\
\text { malformations }\end{array}$ & $7(13.0)$ & $3(42.9)^{*}$ \\
\hline Mode of delivery & $53(98.1)$ & \\
\hline Cesarean section & & $42(79.2)$ \\
\hline Vaginal delivery & & $11(20.8)$ \\
\hline $\begin{array}{l}\text { Cesarean section } \\
\text { indicated for } \\
\text { gastroschisis }\end{array}$ & $\begin{array}{c}41 / 42 \\
(97.6 \%)\end{array}$ & $40(75.5)$ \\
\hline $\begin{array}{l}\text { *Degree of kinship of the } f \\
\text { child; SD: standard deviation } \\
\text { P75: 75th percentile. Source } \\
\text { (2016). }\end{array}$ & member & $\begin{array}{l}\text { nalformation is } \\
\text { 25th percentile; } \\
\text { hor. Study data }\end{array}$ \\
\hline
\end{tabular}




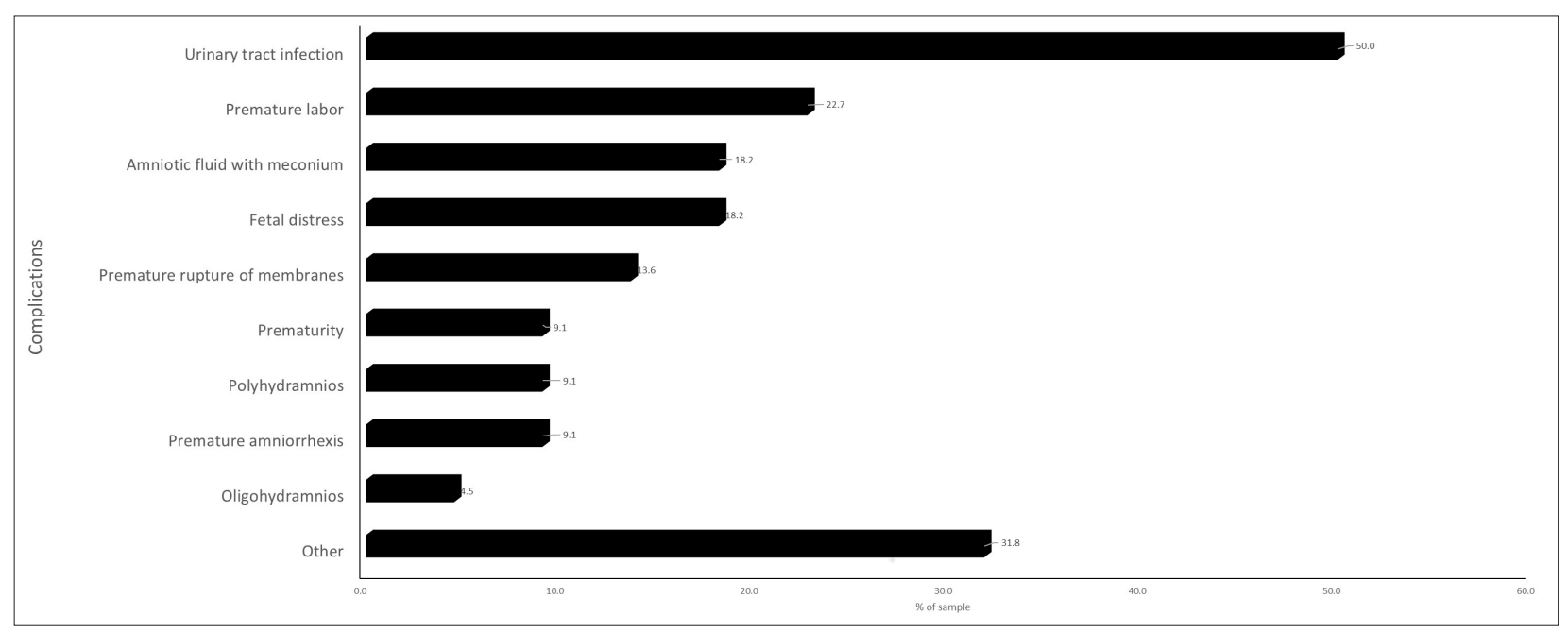

Figure 1: Sample distribution of neonatal complications $(n=22)$.

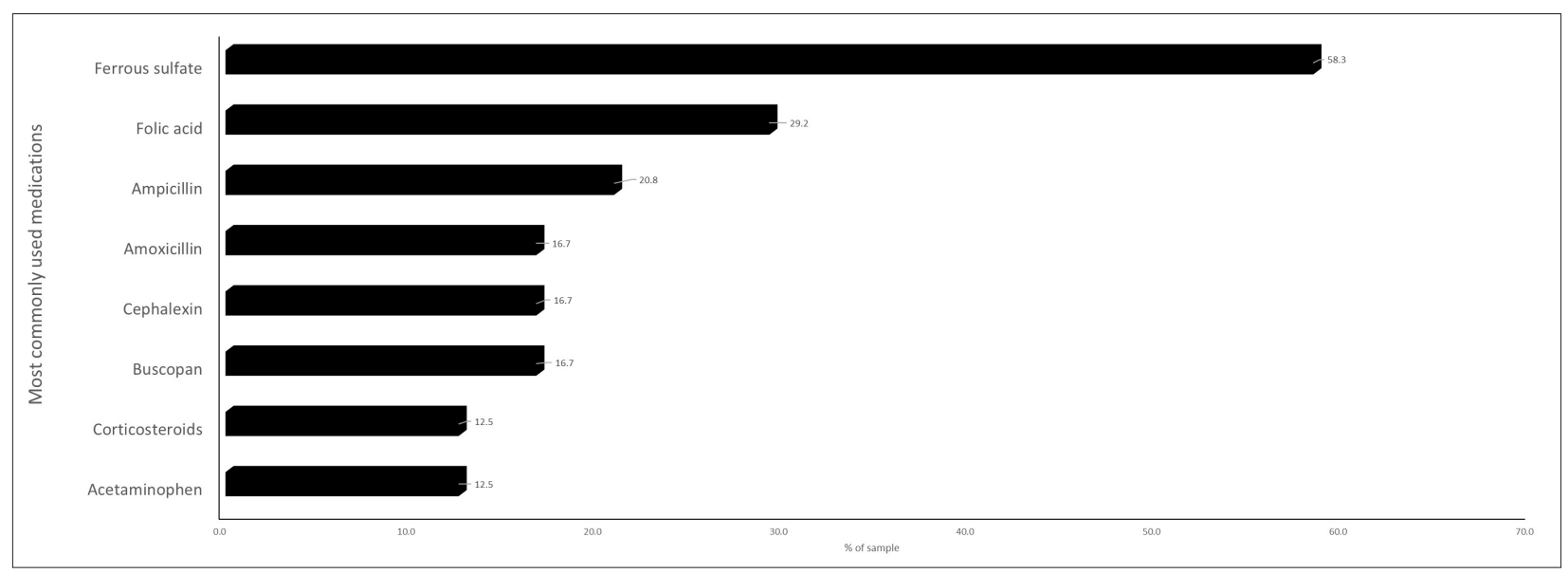

Figure 2: Most commonly used medications during pregnancy $(n=24)$.

the most frequent of which were external exposure of stomach (25\%), external exposure of small intestine, and heart murmur (18.75\%) (figure 5).

\section{DISCUSSION}

The present study revealed the profile of NB diagnosed with gastroschisis and treated at a large public hospital in Porto Alegre, southern Brazil. The prevalence of gastroschisis in our study was $0.11 \%$, i.e., 54 cases, which is in contrast to a study that reported a prevalence of 4.53 cases per 10,000 live births in Porto Alegre from 2000 to $2004^{2}$. In South America, the Latin American Collaborative Study of Congential Malformations (Estudo Colaborativo Latino-Americano de Malformações Congênitas, ECLAMC) found a prevalence of 2.9 per 10,000 live births ${ }^{13,14}$.
In terms of educational level, $18.8 \%$ of women had a high school degree and only $1.9 \%$ had a higher education degree. In line with our results, a survey conducted in Brazil in 2009 showed that $8.2 \%$ of parturient women had from 0 to 3 years of education, $28.7 \%$, had from 4 to 7 years of education, and $63.1 \%$, had eight years or more of education ${ }^{15}$.

With regard to associated risk factors, some authors $^{16}$ state that early maternal age is a risk factor for gastroschisis. However, this malformation may also occur among infants of advanced age mothers, resulting from factors such as hormone and biochemical deficiencies ${ }^{6}$. The literature findings were consistent with those of the present study, which found a mean maternal age of 20.2 years. Other factors associated with gastroschisis may be related to maternal habits, primiparity, and socioeconomic 
Table 3: Profile of NBs with gastroschisis $(n=54)$.

\begin{tabular}{|c|c|c|}
\hline Variables & $\begin{array}{c}\text { Total } \\
\text { sample } \\
\text { n (\%) }\end{array}$ & $\begin{array}{c}\text { Descriptive } \\
\text { statistics } \\
\text { n (\%) }\end{array}$ \\
\hline Stillborn & $54(100)$ & $0(0.0)$ \\
\hline Infant's sex & $54(100)$ & \\
\hline Male & & $27(50.0)$ \\
\hline Female & & $27(50.0)$ \\
\hline $\begin{array}{l}\text { Birth weight }(g)-\text { mean } \pm \\
\text { SD }\end{array}$ & $52(96.3)$ & $2427 \pm 494$ \\
\hline $\begin{array}{l}\text { 1-minute Apgar score - md } \\
\text { (P25-P75) }\end{array}$ & $51(94.4)$ & $8(7-9)$ \\
\hline $\begin{array}{l}\text { 5-minute Apgar score - md } \\
(\mathrm{P} 25-\mathrm{P} 75)\end{array}$ & $51(94.4)$ & $9(9-9)$ \\
\hline $\begin{array}{l}\text { Gestational age by the } \\
\text { Capurro method (weeks) - } \\
\text { mean } \pm \text { SD }\end{array}$ & $30(55.6)$ & $37.8 \pm 1.8$ \\
\hline $\begin{array}{l}\text { Other associated } \\
\text { malformations }\end{array}$ & $40(74.1)$ & $16(40.0)$ \\
\hline Type of closure & $51(94.4)$ & \\
\hline Primary & & $37(72.5)$ \\
\hline Secondary & & $14(27.5)$ \\
\hline $\begin{array}{l}\text { Hours of life }- \text { md } \\
(\text { P25 - P75) }\end{array}$ & $24(44.4)$ & $2.5(1-22)$ \\
\hline $\begin{array}{l}\text { Late postpartum deaths - } \\
\mathrm{n}(\%)\end{array}$ & $54(100)$ & $4(7.4)$ \\
\hline $\begin{array}{l}\text { SD: standard deviation; md: m } \\
\text { P75: 75th percentile. Source: desi } \\
\text { (2016). }\end{array}$ & n; P25: & $\begin{array}{l}\text { h percentile; } \\
\text { or. Study data }\end{array}$ \\
\hline
\end{tabular}

status, as shown in other studies ${ }^{6}$ that found an increased risk of gastroschisis among primiparous women, those with low economic and educational status, and those with reported use and abuse of illegal drugs, such as crack, and/or tobacco during pregnancy. Drug consumption during pregnancy is associated with maternal and fetal complications.

Illegal drugs deregulate blood flow to the fetus and may lead to uteroplacental insufficiency causing premature placental detachment, intrauterine growth restriction, low birth weight, premature amniorrhexis, amniotic fluid with meconium, preterm labor, and congenital malformations ${ }^{17}$.

According to the present study, the use of tobacco and illicit drugs during pregnancy was reported in $21.9 \%$ and $6.3 \%$ of medical records, respectively. Other teratogenic agents during pregnancy include aspirin, ibuprofen, and/or pseudoephedrine when taken during embryonic development ${ }^{5,18}$. International studies $^{6}$ showed a significant association between UTI at conception and presence of gastroschisis. As for fetal susceptibility to medications, it is important to consider the gestational age when the mother started taking the medication, because

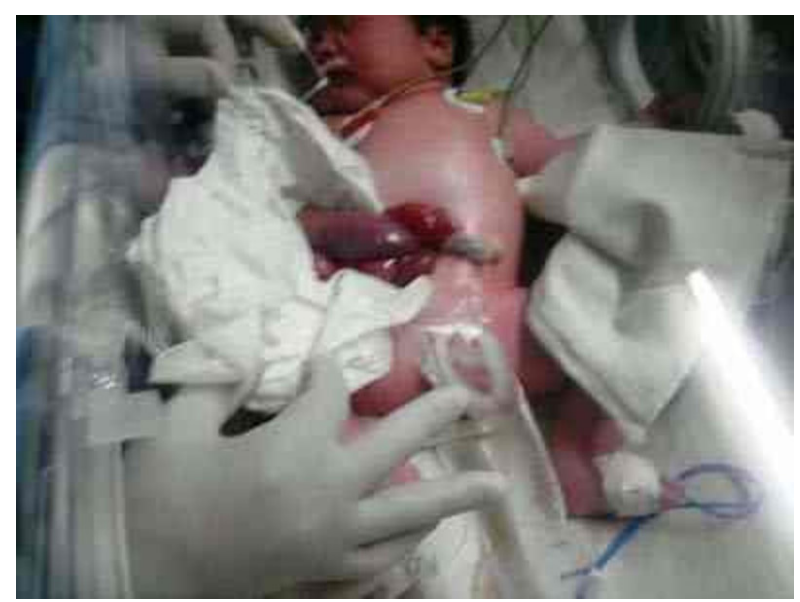

Figure 3: Postoperative image of newborn with gastroschisis.

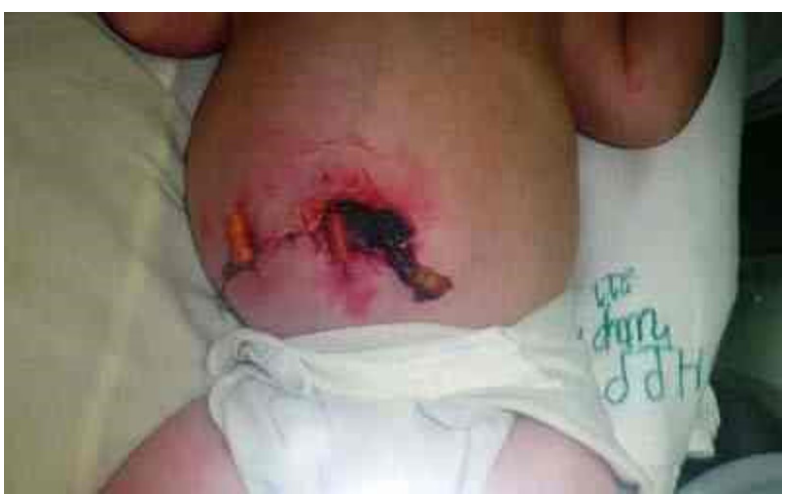

Figure 4: Postoperative image of newborn with gastroschisis in the supine position.

some pharmacological substances lead to changes in fetal embryonic development ${ }^{18}$. These results are in agreement with those found in the present study, in which 24 medical records reported treatment for UTI during pregnancy.

With regard to mode of delivery, some studies ${ }^{3}$ stated that early prenatal diagnosis of gastroschisis is important to determine mode of delivery. However, the most appropriate mode of delivery for this condition is still controversial. Studies did not show any benefit from routine surgical delivery ${ }^{19-21}$ except for the possibility of planning neonatal care together with the neonatology team. In the present study, $79.2 \%$ of infants were born by cesarean section, of which $97.6 \%$ were performed with medical indication due to gastroschisis. This condition may be diagnosed by ultrasound after nearly 12 weeks gestation. This test allows to diagnose congenital malformations and to identify type, size, location, and content of the defect, being thus crucial for pregnancy follow-up and for the transfer of pregnant women to a reference center 


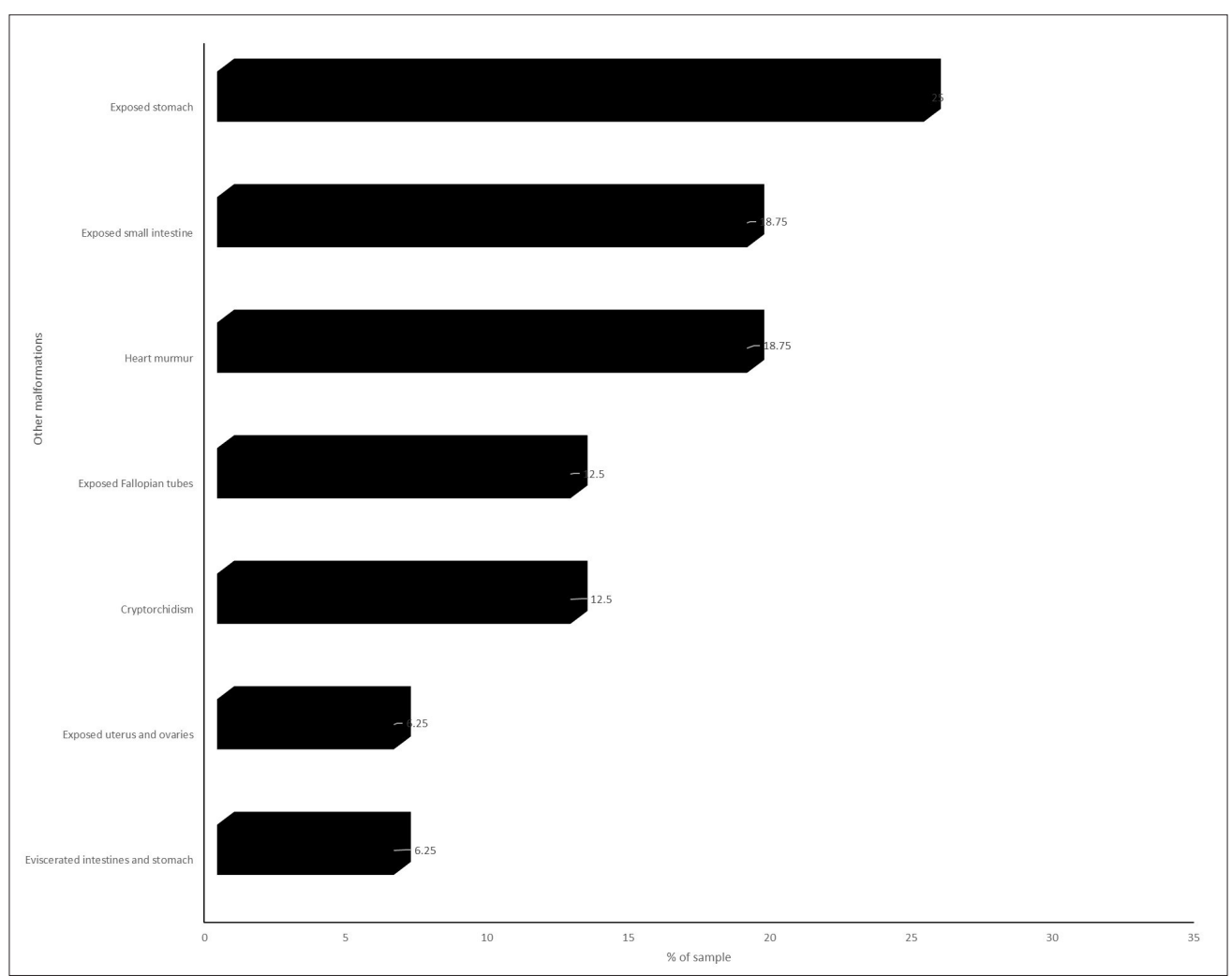

Figure 5: Sample distribution of associated malformations $(n=16)$.

in order to choose the best decision making for the treatment of neonates with gastroschisis ${ }^{7}$.

The birth plan includes women support, preparations for childbirth, and surgical treatment of the diagnosed complications. Therefore, prenatal diagnosis makes it possible to develop a birth plan, to arrange the transfer of pregnant women to the reference hospital, and to reduce the time between delivery and surgical procedure, thus increasing survival expectancy among neonates ${ }^{3}$.

Health care for pregnant women is complicated by the fact that prenatal care is provided by an obstetrician and childbirth is conducted by another professional who is not familiar with the case, which may undermine the counter-referral from the health care center to the referral institution ${ }^{22}$.

Currently, mortality rates from gastroschisis are low and survival may reach $90 \%$, as shown by Snyder ${ }^{23}$ and Driver et al. ${ }^{24}$,consistent with findings of the present study, in which mortality rate was $7.4 \%$. However, a study conducted in the state of Minas Gerais, southeastern Brazil, found higher mortality rates $(14.7 \%)$ compared to developing countries ${ }^{11}$, with deaths usually occurring among neonates with intestinal impairment or sepsis ${ }^{7}$.

With regard to treatment of the NB with gastroschisis in the immediate postpartum period, a silo, i.e., a polyvinyl chloride (PVC) bag, helps prevent heat and fluid loss and allows for intestinal loops to be returned to the abdominal cavity until the surgical closure of the abdominal wall ${ }^{7}$. Our findings were consistent with those of a previous study ${ }^{2}$ aiming to analyze the perinatal mortality rate in cases of gastroschisis and possible associated factors, which found that silo placement was the primary procedure in $68.8 \%$ of the cases, with a mean intervention time of 3 hours. The present study obtained similar results, considering that $72.5 \%$ of neonates underwent primary closure and median time for abdominal wall closure was 2.5 hours. Although there is consensus that urgent repair surgery is required, there is no consensus on the time interval between birth and surgery ${ }^{7}$. A study shows that intervals greater than 4 hours are associated with greater mortality ${ }^{25}$, but a Canadian study found that there was no difference in mortality rates between patients operated before the age of 6 hours and those operated at a later age ${ }^{26}$.

With regard to associated malformations, the literature ${ }^{4}$ reports that there was a low number of malformations associated with gastroschisis. Conversely, the present study observed that $40 \%$ of cases of gastroschisis had some type of associated malformation and external exposure of other visceral content, including heart murmur (18.75\%), cryptorchidism (12.5\%), congenital 
clubfoot and micrognathism (6.25\%). As for exposed content, this study observed that $25 \%$ of NBs presented with intestine evisceration, $6.25 \%$ with stomach evisceration, $18.75 \%$ with small bowel evisceration, and $12.5 \%$ with fallopian tube evisceration.

Birth weight is an important factor in the progression of neonates with gastroschisis. Intrauterine growth restriction, as observed by low birth weight $(\leq 2,500 \mathrm{~g})$, is one of the frequent complications in neonates with gastroschisis ${ }^{27}$. In this study, infants who died at birth had a mean birth weight below $1,800 \mathrm{~g}$, showing that low birth weight and prematurity are associated with mortality ${ }^{2}$. Intrauterine growth restriction may be influenced by loss of nutrients and proteins through intestinal exposure to amniotic fluid causing secondary growth deprivation ${ }^{19}$. This fact may lead to a lower tolerance to the progression of enteral feeding, requiring longer time of parenteral nutrition and thus longer hospital stay ${ }^{11}$. It is worth emphasizing that this study did not investigate variables related to parenteral nutrition, antibiotic therapy, and length of hospital stay among cases of gastroschisis.

Although the prevalence rates found here differ from those of previous studies, our findings on related causes, such as maternal age, use of drugs, and types of abdominal closure, are similar to those of other studies on gastroschisis

Early prenatal diagnosis of gastroschisis has an important relationship with the best neonatal outcomes, because early diagnosis makes it possible to monitor fetal conditions, to choose mode of delivery, and to follow women during pregnancy.

The multidisciplinary team plays an important role in the care of NBs with gastroschisis, especially with regard to guiding and educating patients' family and their support network.

It is essential to refer and counter-refer these cases from and to services that will follow neonates and their families so as to provide care in a humane, safe and qualified way.

Since this was a retrospective study, it was limited by the search of information in medical records, especially those from cases transferred from other maternity hospitals to the study hospital, which may affect study results. New studies are suggested to assess prenatal care, postoperative care, and neonatal intensive care.

\section{REFERENCES}

1. Melo WA, Zurita RCM, Uchimura TT, Marcon SS. Anomalias congênitas: fatores associados à idade materna em município sul brasileiro, 2000 a 2007. Rev Eletr Enf. 2010;12(1):7382. http://dx.doi.org/10.5216/ree. v12i1.5994.

2. Calcagnotto $H$, Müller ALL, Leite JCL, Sanseverino MTV, Gomes $\mathrm{KW}$, Magalhães JAA. Fatores associados à mortalidade em recém-nascidos com gastrosquise. Rev Bras Ginecol Obstet. 2013;35(12):549-53. PMid:24500509. http://dx.doi.org/10.1590/S010072032013001200004

3. Montalto PS, Conz CA. Proposta de um plano de cuidados imediatos do enfermeiro ao recém-nascido com gastrosquise, baseado no NANDA/ NIC. Pediatr Mod [serial online] 2012 [cited 2016 May 31];48(7):273-89. Available from: http://www.moreirajr. com.br/revistas.asp?fase $=$ r003\&id materia $=5092$

4. Nhoncanse GC, Germano CMR, Avó LRS, Melo DG. Aspectos maternos e perinatais dos defeitos congênitos: um estudo caso-controle. Rev Paul Pediatr. 2014;32(1):24-31. PMid:24676186.
http://dx.doi.org/10.1590/S010305822014000100005.

5. Conde A, Zunini S, Sosa C. Estudio descriptivo de los nacimientos con gastrosquisis en el Centro Hospitalario Pereira Rossell Dres. Rev Med Urug [serial onlinet] 2013 [cited 2015 May 12];29(1):16-25. Available from: http:// www.rmu.org.uy/revista/2013v1/art4. pdf

6. Brito VRS, Souza FS, Medeiros FAL, Coura AS, Gadelha FHA, França ISX. Incidência de malformação congênita e atenção em saúde nas instituições de referência. Rev. Rene [serial online]. 2010 [cited 2015 May 14];11(4):29-37. Available from: http:// www.revistarene.ufc.br/vol11n4_pdf/ a03v11n4.pdf

7. Santos HC. Gastrosquise: diagnóstico pré-natal, segmento e análise de fatores prognósticos para óbitos em recém-nascidos [dissertation]. Porto Alegre: Faculdade de Medicina, Universidade Federal do Rio Grande do Sul; 2010. [cited 2015 Oct 20]. Available from: https:// www.lume.ufrgs.br/bitstream/ handle/10183/26142/000757161. pdf?sequence $=1$
8. Barbeiro FMS, Maciel DBV Assistência de enfermagem ao recém-nascido com gastrosquise. In: Anais do $1^{\circ}$ Congresso Brasileiro de Enfermagem Neonatal [online]; 2010, Rio de Janeiro. Rio de Janeiro: ABENFO; 2010. p. 81-4. [cited 2015 Oct 6]. Available from: http://abenfo. redesindical.com.br/arqs/outros/211_ ANAIS-ENFERMAGEM.pdf

9. Tannuri AC, Silva LM, Leal JG, Moraes AC, Tannuri U. Does administering albumin to postoperative gastroschisis patients improve outcome? Clinics. 2012;67:107-11.

10. Tamez RN. Enfermagem na UTI neonatal: assistência ao recémnascido de alto risco. 5th ed. Rio de Janeiro: Guanabara Koogan; 2013.

11. Alves FMS, Miranda ME, Aguiar MJB, Viana MCFB. Nutritional management and postoperative prognosis of newborns submitted to primary surgical repair of gastroschisis. J Pediatr. 2016;92(3):26875. http://dx.doi.org/10.1016/j. jped.2015.07.009.

12. Reis AT. Afecções cirúrgicas e malformações congênitas no período neonatal. In: Araújo LA. Enfermagem 
na prática materno-neonatal. Rio de Janeiro: Guanabara Koogan; 2012. p. 261-76.

13. Castilla EE, Mastroiacovo P, Orioli IM. Gastroschisis: international epidemiology and public health perspectives. Am J Med Genet C Semin Med Genet. 2008;148C:16279.

14. Santiago-Munoz PC, Mclntire DD, Barber RG, Megison SM, Twicler DM, Dashe JS. Outcomes of pregnancies with fetal gastroschisis. Obstet Gynecol. 2007;110:663-8.

15. Brasil. Secretaria de Vigilância em Saúde. Departamento de Análise de Situação em Saúde. Saúde Brasil 2010: uma análise da situação de saúde e de evidências selecionadas de impacto de ações de vigilância em saúde. Brasília: Ministério da Saúde; 2011.

16. Ortega-Garcia JA, Soldin OP, SánchezSauco MF, Cánovas-Conesa A, Gomaríz-Peñalver V, Jaimes-Vega $\mathrm{DC}$, et al. Violence against women and gastroschisis: a case-control study. Int J Environ Res Public Health. 2013;10(10):5178-90. PMid:24142184

17. Marangoni SR, Oliveira MLF. Uso de crack por multípara em vulnerabilidade social: história de vida. Cienc Cuid
Saude [serial online] 2012 [cited 2016 May 09];11(1):166-72. Available from: http://ojs.uem.br/ojs/index.php/ CiencCuidSaude/article/view/18874/pdf

18. Rocha RS, Bezerra SC, Lima JWO, Costa FS. Consumo de medicamentos, álcool e fumo na gestação e avaliação dos riscos teratogênicos. Rev Gaúcha Enferm [serial online]. 2013 [cited 2015 May 18];34(2):37-45.

Available from: http://seer.ufrgs.br/ RevistaGauchadeEnfermagem/article/ view/27191

19. Hunter AG, Stevenson RE. Gastroschisis: clinical presentation and associations. Am J Med Genet C Semin Med Genet. 2008;148C:219-30.

20. Arnold MA, Chang DC, Nabaweesi $\mathrm{R}$, Colombani PM, Fischer AC, Lau $\mathrm{HT}$, et al. Development and validation of a risk stratification index to predict death in gastroschisis. J Pediatr Surg. 2007;42:950-5.

21. Jager LC, Heij HA. Factors determining outcome in gastroschisis: clinical experience over 18 years. Pediatr Surg Int. 2007;23:731-6.

22. Vieira DKR, Horovitz DDG, Llerena JC Jr. Avaliação genética itinerante de crianças e adolescentes com deficiências vinculadas à Estratégia de Saúde da Família. Rev Bras Med
Fam Comunidade [serial online]. 2012 [cited 2016 May 10];7(24):196-203. Available from: http://www.rbmfc.org. $\mathrm{br} / \mathrm{rbmfc} /$ article/view/485/505

23. Snyder $\mathrm{Cl}$. Outcome analysis for gastroschisis. J Pediatr Surg. 1999;34:1253-6.

24. Driver CP, Bruce J, Bianchi A, Doig CM, Dickson AP, Bowen J. The contemporary outcome of gastroschisis. J Pediatr Surg. 2000;35:1719-23.

25. Vilela PC, Amorin MMR, Falbo GH No, Santos LC, Santos RVH, Correia C. Fatores prognósticos para óbito em recém-nascidos com gastrosquise. Acta Cir Bras. 2002;17(Suppl 1):1720.

26. Skarsgard ED, Claydon J, Bouchard S, Kim PC, Lee SK, Laberge JM, et al. Canadian Pediatric Surgical Network: a population-based pediatric surgery network and database for analyzing surgical birth defects. The first 100 cases of gastroschisis. J Pediatr Surg. 2008;43:30-4.

27. Blakeloc R, Upadhyay V, Kimble R, Pease P, Kolbe A, Harding J. Is a normally functioning gastrointestinal tract necessary for normal growth in late gestation? Pediatr Surg Int. 1998;13:17-20. 